Sitasi artikel ini (APA $6^{\text {th }}$ Edition style):

Rozi, F., \& Firman, R. N. (2018). Ahok dan Habib Rizieq Shihab dalam Isu Foto Hoax: Opini PGI dan HKBP di Kota Medan. MUKADIMAH, 2(1), 44-56.

\title{
Ahok dan Habib Rizieq Shihab dalam Isu Foto Hoax: Opini PGI dan HKBP di Kota Medan
}

\author{
Fakhrur Rozi ${ }^{1} \&$ Rizky N. Firman ${ }^{2}$ \\ 1Program Studi Ilmu Komunikasi, Fakultas Ilmu Sosial UIN Sumatera Utara, Medan \\ 2Program Studi Ilmu Komunikasi, Sekolah Tinggi Ilmu Komunikasi “Pembangunan", Medan \\ roziajalagi@gmail.com dan rizkyfirman_786@gmail.com
}

\begin{abstract}
ABSTRAK
Kasus penistaan agama yang dilakukan oleh Basuki Tjahaja Purnama (Ahok) pada tahun 2016 menjadi isu nasional dan menimbulkan pro-kontra. Penelitian ini menggunakan metode deskriptif-kualitatif yang bertujuan mendeskripsikan kasus penistaan agama di media sosial yang melahirkan opini mayor dan opini minor di masyarakat. Artikel ini menguraikan opini minoritas lebih pada ormas agama Kristen tentang foto hoax Ahok dan Habieb Rizieq Shihab yang beredar di Instagram dengan Teori Spiral Keheningan. Penelitian ini menghasilkan temuan: Pertama, opini mayoritas terhadap foto hoax pada akun @aganharahap terkait mengakibatkan opini minoritas cenderung bungkam. Kedua, PGI dan HKBP menyadari sebuah foto hoax Ahok dan Habib Rizieq Shihab tidak memiliki unsur kebencian dan tidak perlu dikhawatirkan. Ketiga, bentuk perlawanan opini minoritas terlihat dalam Aksi Seribu Lilin untuk Ahok.
\end{abstract}

Kata kunci: Opini publik, foto hoax, Instagram.

\section{PENDAHULUAN}

Kasus penistaan agama yang dilakukan oleh Basuki Tjahaja Purnama (Ahok) di Kepulauan Seribu menjadi opini yang menyelimuti benak mayoritas warga Indonesia. Pidato Ahok saat melakukan kunjungan kerja di Pulau Pramuka, Kepulauan Seribu, menghina agama. Ucapan itu bermula saat Ahok meninjau program pemberdayaan budi daya ikan kerapu di Pulau Pramuka. Menurutnya, program itu akan tetap dilanjutkan meski dia nanti tidak terpilih lagi menjadi Gubernur di Pilkada Jakarta 2017, sehingga warga tak harus memilihnya hanya semata-mata ingin program itu terus dilanjutkan. "Kan bisa saja dalam hati kecil Bapak Ibu, nggak pilih saya karena dibohongi (orang) pakai Surat Al Maidah: 51 macam-macam itu. Itu hak Bapak Ibu. Kalau Bapak Ibu merasa nggak bisa pilih karena takut masuk neraka, dibodohin, begitu, oh nggak apa-apa, karena ini panggilan pribadi. Bapak Ibu, Program ini (pemberian modal bagi budi daya kerapu) jalan saja. Jadi Bapak Ibu nggak usah merasa nggak enak karena nuraninya nggak bisa pilih Ahok," ujarnya ("Pidato di Kepulauan Seribu dan hari-hari hingga Ahok menjadi tersangka," 2016). 
Kemudian ucapan Ahok itu ada yang merekam, dan viral di media sosial. Beberapa waktu berselang, ucapan Ahok tersebut dilaporkan oleh Front Pembela Islam (FPI), dan Majelis Ulama Indonesia (MUI) Sumatera Selatan kepada polisi. Sejumlah organisasi lain menyusul melaporan Ahok termasuk ribuan orang dari berbagai ormas Islam yang dipimpin oleh Habieb Rizieq Shihab (Imam Besar FPI) dalam unjuk rasa di depan Balai Kota Jakarta. Tuntutan massa adalah agar Ahok segera dihukum. Kemudian Kepolisian Republik Indonesia melakukan gelar perkara secara terbuka terbatas untuk menentukan status hukum Ahok. Ahok ditetapkan sebagai tersangka dalam kasus dugaan penistaan agama dan divonis dua tahun hukuman penjara. Ahok menyatakan menerima hasil putusan pengadilan dan akan mengikuti proses hukum dengan keyakinan tidak bersalah.

Dinamika kasus penistaan agama yang dilakukan oleh Ahok menjadi realitas baru yang dihadapi. Banyaknya pendapat pro maupun kontra telah mewarnai panggung media. Media dituntut untuk menjalankan fungsinya sebagai pemasok dan menyebarluaskan informasi yang diperlukan. Untuk menentukan sikap dan memfasilitasi pembentukan opini publik dengan menempatkan dirinya sebagai wadah independen. Keterlibatan media dalam konflik ini menjadi suatu keniscayaan jurnalistik. Bagi insan media, konflik agama bagaikan oase yang tak pernah kering di padang pasir. Karena dianggap penting dalam proses produksi berita. Daya pikat konflik agama terhadap ranah psikologi khalayak pembaca sangat besar, sehingga konflik agama selalu ditempatkan sebagai nilai berita yang penting (Sudibyo, 2001).

Selang beberapa waktu setelah video penistaan agama menjadi pemberitaan di media mainstream, muncul sebuah foto di media sosial Instagram dari akun @aganharahap. Foto yang diposting pada 18 Oktober 2016 tersebut, gambar Ahok sedang berjabat tangan dengan Habib Rizieq Shihab dengan wajah keduanya tersenyum. Foto tersebut seakan ingin menunjukkan Ahok dan Habib Rizieq Shihab telah berdamai (gambar 1). Namun ternyata, foto tersebut adalah foto palsu atau hoax yang hasil manipulasi digital dari dua foto yang berbeda (gambar 2).

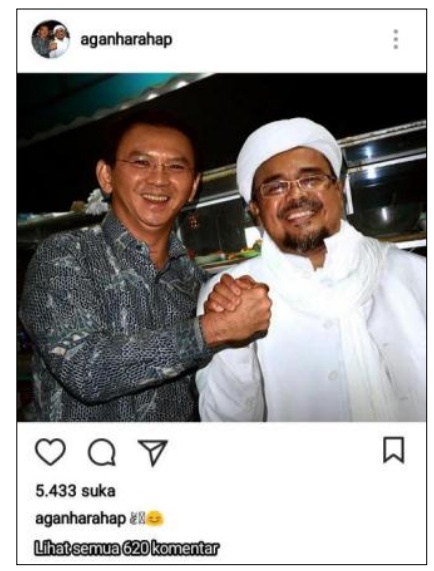

Gambar 1. Foto Hoax di akun Instagram @aganharahap

Sumber: Instagram/aganharahap
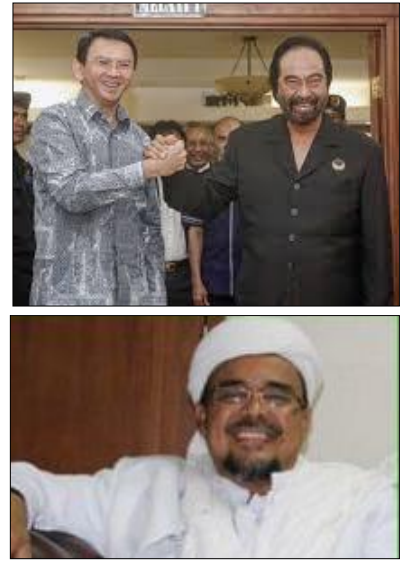

Gambar 2. Foto Asli yang beredar di internet

Sumber: Google.com 


\section{METODE DAN FOKUS PENELITIAN}

Penelitian ini menggunakan metode deskriptif-kualitatif dengan fokus pada akun Instagram @aganharahap. Karena akun ini sangat intens menunggah foto editan yang berhubungan peristiwa aktual di masyarakat menyertakan gambar editan tokoh publik. Akun @aganharahap memiliki puluhan ribu pengikut dan setiap unggahannya mendapat respons yang signifikan dari pengikutnya maupun pengguna instagram lainnya. Akun media sosial yang mengunggah foto hoax hasil editan memang cukup banyak beredar di internet. Memproduksi foto hoax atau memanipulasi foto memang tidak hanya dilakukan oleh akun @aganharahap, ada banyak akun lainnya yang melakukan itu. Tetapi hanya akun @aganharahap yang berani mengunggah foto-foto terkait pro-kontra yang mengemuka di ruang publik dan masyarakat seperti foto hoax Ahok dan Habib Rizieq Shihab, yang saat itu tengah berada dalam pusaran kasus penistaan agama. Perlu dicatat juga, akun @aganharahap adalah akun asli, bukan akun anonim atau akun robot atau digerakkan mesin (spambot) yang jumlahnya mencapai jutaan akun Instagram (Heriyanto, 2015).

\section{KERANGKA TEORETIK DAN KONSEPTUAL}

Di era digital seperti sekarang ini, Instagram dianggap sebagai media baru yang sangat digandrungi oleh masyarakat sebagai wadah penyalur aspirasi. Kehadiran media sosial baru mengakibatkan informasi semakin mudah dicari dan terbuka. Media sosial adalah medium internet yang memungkinkan pengguna merepresentasikan dirinya maupun berinteraksi, bekerja sama, berbagi, berkomunikasi dengan pengguna lain, dan membentuk ikatan sosial secara virtual. Media sosial memberikan keleluasaan bagi khalayak untuk ikut dalam kompetisi menyebarkan informasi atau peristiwa yang terjadi di sekitar mereka (Nasrullah, 2015, p. 1).

Kemunculan foto tersebut ternyata menjadikan kondisi semakin tidak kondusif. Asumsi dominan masyarakat bahwa foto itu merupakan foto yang dibuat oleh pendukung Ahok. Ada juga yang berasumsi bahwa foto itu merupakan foto yang dibuat untuk mengembalikan citra Ahok. Dan tak banyak pula yang berkomentar dengan kata-kata kasar yang tak pantas. Asumsiasumsi ini tertulis di kolom komentar foto yang tersebar pada akun @aganharahap tersebut.

Proses berkomunikasi di media sosial seperti berjalan tanpa standar etika yang jelas, sehingga kerap menimbulkan kebingungan dan kekacauan. Individu menunjukkan sisi post-human atau sisi yang benar-benar menunjukkan jati diri di media sosial. Semua orang dikondisikan untuk berbicara secara lugas, spontan, dan instan seakan-akan sedang berada pada level komunikasi interpersonal. Bahkan sebagian pengguna media sosial cenderung bersikap seolah-olah mengetahui segalanya dalam mengomentari orang lain. Inilah penyebab sebagian pengguna lainnya memilih untuk menarik diri dari perdebatan di media sosial agar menghindari percekcokan yang tidak perlu (Sudibyo, 2001). 
Hubungan antara komunikan terhadap pesan yang terdapat di dalam foto hoax itu memiliki dampak yang berbeda secara nilai bagi pengguna itu sendiri, yaitu pembentukan makna terhadap isi media yang dilihat dari sudut pandang dan fokus masing-masing. Isi media adalah hasil para pekerja media mengkonstruksikan berbagai realitas yang dipilihnya. Sehingga dapat digarisbawahi adalah bagaimana pesan yang diterima oleh komunikan terbentuk oleh konstruksi realitas yang diciptakan oleh penyebar foto yang bertujuan untuk mempengaruhi makna.

Dari fenomena ini, peneliti juga melihat ada kelompok masyarakat yang kurang berani berpendapat karena takut berseberangan dengan opini dominan atau masyarakat mayoritas. Ini semakin menambah keingintahuan peneliti tentang bagaimana sudut pandang pemaknaan foto hoax tersebut dari anggota ormas (organisasi masyarakat) agama Kristen. Karena dalam kasus Ahok, suara anggota ormas agama Kristen sangat minim. Sedikitnya pemberitaan tentang pendapat mereka, membuat peneliti semakin tertarik untuk mengetahui pendapat mereka tentang foto hoax antara Ahok dan Habieb Rizieq Shihab terkait kasus penistaan agama yang menimpa Ahok yang merupakan penganut agama Kristen.

Ormas agama merupakan salah satu bentuk interaksi yang mana kepercayaan agama mereka mempunyai dampak besar bukan hanya bagi kehidupan dirinya, melainkan juga dapat berdampak sosial. Pola pikirpun terbentuk sehingga menciptakan konsistensi berpikir dalam menilai suatu informasi terkait agama yang mereka anut. Agama merupakan kekuatan yang mempunyai pengaruh besar dalam kehidupan manusia. Agama mempunyai keterkaitan dengan berbagai aspek kehidupan, seperti keluarga, masyarakat, ekonomi, dan politik. Terdapat hubungan dialektik antara agama dan aspek kehidupan sosial lainnya. Hal inilah yang mendasari terbentuknya suatu ormas agama.

Individu dalam ormas agama mengidentifikasikan perilakunya dalam kehidupan sehari-hari. Mereka berpendapat bahwa agama memiliki ciri khusus dan sangat cocok untuk mengurangi perasaan ketidakpastian diri. Agama menghasilkan sistem kepercayaan preskriptif normatif yang berhubungan dengan kehidupan sehari-hari. Ormas agama menghasilkan panduan moral dan aturan hidup yang meliputi kehidupan seseorang dan mengurangi ketidakpastian (Haryanto, 2015, p. 41).

Sebagai contoh, kepercayaan dan nilai-nilai agama memotivasi manusia dengan tindakan tertentu dan organisasi keagamaan dapat mengorganisasi maka agama telah berdimensi sosial. Seperti yang terjadi pada aksi bela Islam pada tanggal 2 Desember 2016 (Aksi 212) di pelataran Monas Jakarta, menggerakkan kurang lebih tujuh juta masa turun ke jalan menuntut keadilan terkait kasus penistaan agama yang dilakukan Ahok.

Kepercayaan dan nilai-nilai agama memotivasi manusia dengan tindakan dan membentuk pola pikir yang konsisten terhadap agama juga diaplikasikan oleh para biarawati. Biarawati adalah seorang perempuan yang 
secara sukarela meninggalkan kehidupan duniawi dan mengabdikan hidupnya untuk kehidupan agama di suatu biara atau tempat ibadah. Istilah ini dapat ditemui di berbagai agama seperti Kristen dan Buddha. Biarawati dalam agama Katolik adalah perempuan yang tergabung dalam suatu tarekat atau ordo religius. Di Indonesia para biarawati biasanya dipanggil suster. Para suster biasanya bekerja di bidang pendidikan (formal dan nonformal), kesehatan, dan pelayanan sosial di lingkungan gereja atau masyarakat umum. Seperti halnya pastor, biarawati tidak menikah karena telah berjanji mengabdikan diri secara sukarela untuk Tuhan, untuk melaksanakan suatu tindakan yang lebih sempurna dalam suatu komunitas religius.

Agama selanjutnya mempengaruhi banyak aspek kehidupan manusia, misalnya temuan Kyle C. Kopko yang menyebutkan agama mempunyai efek partisipasi politik. Doktrin Gereja Mennonite AS melarang aktivitas politik karena sifat duniawinya. Meskipun demikian belum ada kejelasan doktrin agama tradisonal apakah juga mempengaruhi partisipasi politik. Kenyataannya bahwa jemaah gereja Mennonite menunjukkan aktivitas politik yang rendah (Haryanto, 2015; Kopko, 2012).

Karena identitas agama merupakan salah satu identitas yang sensitif ketika mendapat serangan atau ancaman dari komunitas lain, maka hal ini semakin mendorong peneliti untuk mencari tahu lebih dalam pendapat ormas agama Kristen tentang foto hoax Ahok dan Habieb Rizieq Shihab yang beredar di Instagram terkait kasus penistaan agama yang bertujuan untuk mengetahui opini minoritas.

\section{HASIL DAN PEMBAHASAN}

\section{Media Sosial dan Opini Publik}

Tidak dapat dipungkiri, kehadiran media baru semakin memudahkan manusia dalam berkomunikasi. Media baru yang berbasis internet berfungsi sebagai media sosial. Melalui media sosial, pola komunikasi masyarakat tidak lagi terbatas oleh ruang dan waktu. Sebagaimana yang dikatakan oleh Marshall McLuhan dengan teorinya "medium as an extension of human faculties" yang artinya "media sebagai perpanjangan tubuh manusia" (McLuhan, 2008).

Melalui penggunaan media sosial, persahabatan dapat dijalin sekaligus dapat berbagi informasi dengan pengguna lainnya tanpa ada hambatan berupa jarak dan waktu. Media sosial menjadi media interaksi baru yang membuat ruang-ruang bagi masyarakat untuk saling berbagi, bercerita dan menyalurkan ide-idenya. Akibatnya, masyarakat melakukan migrasi virtual untuk berinteraksi di ruang virtual agar dapat berinteraksi dengan pengguna lainnya.

Selain itu Instagram juga sebagai tempat diskusi yang tepat. Komentar yang ditulis seseorang secara bebas akan direspons oleh orang lain, sehingga disini dapat dijadikan sebagai media berukar pikiran. Masyarakat menjadi lebih mudah berkomunikasi namun sekaligus mulai menggerogoti interaksi sosial karena ada kecenderungan lebih banyak berinteraksi di dunia maya ketimbang bertemu bertatap muka. 
Seseorang yang menjadi pengguna Instagram cenderung lebih suka meluahkan perasaannya di media tersebut. Apapun yang dirasakannya, mulai dari marah, senang, galau, hingga rasa kecewa akan diposting dalam bentuk foto atau video dalam akun miliknya. Meskipun terkadang masih ada yang memposting hal-hal mengenai masalah-masalah sosial. Instagram kini telah dianggap sebagai ruang publik untuk menuliskan atau membahas sesuatu yang berhubungan dengan publik.

Dahlgren menyebutkan cara yang berbeda di mana internet dapat membantu: meningkatkan hubungan langsung antara pemerintah dan warga negara; memberikan panggung dan saluran untuk pengacara dan aktivis; menyelenggarakan forum sipil untuk debat dan diskusi; dan juga menambah lebih banyak cabang bagi jurnalisme yang beragam. Adapun cara-cara media dalam mendukung ranah publik adalah sebagai berikut (Dahlgren, 2003):

1) Memperluas ruang untuk debat.

2) Mengedarkan informasi dan gagasan sebagai dasar untuk opini public.

3) Saling menghubungkan warga dengan pemerintah.

4) Menyediakan informasi yang bergerak.

5) Menantang monopoli pemerintah dalam hal politik.

6) Memperluas kebebebasan dan keragaman publikasi.

Berdasarkan penjelasan di atas, dapat katakan bahwa Instagram sebagai media sosial juga berfungsi sebagai ruang publik. Dalam konteks ini, media sosial Instagram menjadi salah satu ruang publik yang terpapar isu penistaan agama Ahok. Akun instagram @aganharahap memproduksi foto hoax (editan) Habib Rizieq Shihab dan Ahok, yang kemudian mewarnai wacana publik tentang konflik kasus penistaan agama tersebut. Foto hoax yang diunggah oleh @aganharahap di akunnya mendapat lebih dari 5.433 penyuka dan 620 komentar yang pro dan kontra (data sampai 26 September 2017).

Penelitian ini, menggunakan Teori Spiral Keheningan untuk membedah fenomena yang diteliti. Teori Spiral Keheningan adalah teori yang menyatakan pendapat pribadi sangat bergantung pada apa yang dipikirkan atau diharapkan oleh orang lain. Pendapat yang dominan akan membuat pendapat yang tidak dominan menjadi diam, sebab ada kecenderungan pendapat yang tidak dominan takut terisolasi oleh pihak yang dominan. Kecenderungan pihak yang menyatakan pendapat dan orang lainnya menjadi diam akan mengawali suatu proses spiral yang meningkatkan kemapanan satu pendapat sebagai pendapat umum dan media massa merupakan salah satu kekuatan lainnya (Morrisan, 2013, p. 65).

Pandangan media dalam menyikapi kasus tertentu ada kalanya bertentangan dengan pendapat individu-individu dalam masyarakat. Pandangan media yang ada kalanya berbeda dengan pandangan masyarakat umum. Noelle-Neumann menyamakan atau menganalogikan situasi tersebut dengan kondisi cuaca yang tidak lazim yang menurutnya menarik dan tampak 
aneh. Hal yang menarik ialah banyak orang yang memilih untuk diam. Orang dari dua sisi yang berbeda mengenai suatu isu akan bervariasi dalam kesediaan mereka untuk mengungkapkan pandangan mereka ke publik (NoelleNeumann, 2008).

Opini publik sebagai apa yang bersifat kontroversial atau hasil sekelompok orang yang secara kolektif tentang sesuatu hal yang bersifat kontroversial. Hal tersebut dikuatkan oleh pendapat Morrisan yang mendefinisikan opini publik sebagai sikap atau tingkah laku yang ditunjukan seseorang kepada publik jika ia tidak ingin dirinya terisolir; dalam hal isu kontroversial, opini publik adalah sikap yang ditunjukan seseorang kepada publik tanpa harus membahayakan dirinya sendiri yaitu berupa pengucilan (Morrisan, 2013, p. 65).

Definisi opini publik lain yang diungkapan oleh Bernard Hennessy adalah bahwa opini publik merupakan komplek preferensi yang dinyatakan sejumlah orang tertentu mengenai isu yang menyangkut kepentingan umum dan di dalamnya terdapat beberapa unsur seperti adanya isu, harus ada kelompok orang yang dapat dikenal yang berkepentingan dengan persoalan tersebut, mengacu pada totalitas pendapat para anggota kelompok tentang suatu isu, ekspresi berbagai pendapat yang menumpuk di sekitar isu, dan adanya besarnya kelompok yang menaruh perhatian terhadap isu (Hennessy, 1954). Opini publik dinyatakan oleh Newsom, Turk dan Kruckeberg bahwa kepercayaan yang diekspresikan oleh media belum tentu fakta melainkan persepsi atau suatu evaluasi terhadap suatu event, perusahaan atau suatu produk (Newsom \& Kruckeberg, 2000, p. 119). Menurut Helena Olii opini publik meliputi hal-hal berikut ini (Olii, 2007, p. 40):

1) Adanya suatu masalah atau situasi yang bersifat kontroversial. Dalam hal ini pemberitaan penarikan produk Indomie di Taiwan yang menimbulkan pro dan kontra.

2) Adanya publik yang secara spontan terpikat kepada suatu masalah, melibatkan diri kedalamnya dan berusaha memberikan pendapatnya.

3) Adanya kesempatan bertukar pikiran atau berdebat mengenai masalah yang kontroversial.

4) Adanya interaksi dari individu-individu dalam publik yang menghasilkan suatu pendapat yang bersifat kolektif untuk diekspresikan.

Opini publik merupakan suatu kegiatan yang terjadi karena adanya sebuah proses. Nimmo mengemukakan pendapatnya tentang pembentukan opini publik, sebagai berikut (Nimmo, 2000, p. 29):

1) Pertikaian yang mempunyai potensi menjadi isu. Publikasi konflik pribadi akan memunculkan pertikaian yang memiliki potensi menjadi isu.

2) Kepemimpinan politik. Pada tahap kedua, ialah munculnya kepemimpian untuk melakukan publikasi. Kepemimpinan seperti itu bisa dilakukan oleh suatu pihak yang terlibat dalam isu yang telah beredar. 
3) Interpretasi personal dan pertimbangan sosial. Interpretasi personal memberikan gambaran tentang opini yang ada, apa yang mungkin dilakukan oleh orang lain, dan apa yang dapat diterima individu.

4) Kesediaan mengungkapkan opini pribadi depan umum. Tahap ini terdiri dari atas pilihan individu untuk menyingkapkan atau tidak menyingkapkan opini pribadi.

Dapat dikatakan opini publik sebuah proses yang berawal dari isu yang kontroversial, kemudian merebak melalui media yang melibatkan beberapa kelompok di dalamnya dan memacu timbulnya berbagai pendapat kolektif terhadap isu tersebut. Kerangka pemikiran yang menjadi alur pembahasan adalah dukungan dasar teoritis dalam rangka memberi jawaban terhadap pendekatan pemecahan masalah. Penyusunan suatu kerangka pemikiran harus bertitik-tolak dari seleksi evidensi-evidensi ilmiah berupa kesimpulan hasil penelitian para pakar ilmiah terdahulu, yang sampai sekarang masih berlaku, dalam arti belum pernah dibantah pihak lain (Ardianto \& Elvinaro, 2012).

\section{Foto Hoax dan Perlawanan Opini Minor}

Umumnya, penyebaran informasi dalam media massa (media sosial) dilakukan untuk membentuk opini publik. Menurut Global Digital Statistic "Digital, Social \& Mobile in 2016" dari We are Social (2016), dari total populasi sebanyak 259,1 juta jiwa di Indonesia, sebesar 88,1 juta orang pengguna internet di Indonesia aktif mengakses media sosial. Sebanyak 66 juta jiwa aktif mengakses media sosial melalui perangkat ponsel. Angka tersebut merupakan angka yang dapat terus bertambah dari waktu ke waktu seiring dengan kemajuan informasi dan teknologi digital (Saputra, 2017).

Akun @aganharahap sendiri memiliki 62.100 pengikut (followers), jumlah yang cukup besar untuk sebuah akun Instagram. Dalam setiap unggahannya, akun ini mendapatkan perhatian yang signifikan dari pengikutnya. Rata-rata unggahan @aganharahap mendapatkan penyuka (like) antara 2500-7.500 penyuka. Akun @aganharahap juga intens mengunggah foto-foto editan tokoh politik nasional dan internasional seperti Joko Widodo, Prabowo Subianto, Fadli Zon, Vladimir Putin, Kim Jong Un, hingga Donald Trump. Agan Harahap merupakan orang asal Sumatera Utara, yang tinggal di Yogyakarta. Dia merupakan mantan fotografer di sebuah majalah musik di Jakarta. Agan Harahap juga dikenal sebagai ahli edit foto. Bahkan, sebuah media nasional memberinya cap sebagai seniman ahli manipulasi foto ("Agan Harahap, Seniman Ahlinya 'Manipulasi Foto,'” 2014).

Dalam konteks penelitian ini, apa yang dilakukan Agan Harahap, dengan menciptakan dan kemudian mengunggah foto hoax adalah bagian dari pembentukan opini publik. Hal ini berdekatan dengan karakteristik opini publik yang disampaikan oleh Nimmo, bahwa opini mempunyai isi yang bermuatan isu atau kabar angin atau apapun itu tentang suatu masalah. Kemudian isu tersebut mempunyai arah. Sejak proses pembentukan opini 
dimulai, opini publik secara alami akan mengarah (diarahkan atau tidak) pada sebuah keputusan final atas opini publik tersebut (Nimmo, 2000, p. 29).

Selanjutnya, unggahan foto hoax juga memenuhi intensitas ketajaman sebagai informasi yang kuat. Dalam konteks foto hoax Ahok dan Habib Rizieq Shihab, informasi semakin kuat, yang bisa dilihat dari ribuan penyuka (like) dan ratusan komentar pada unggahan foto hoax itu, maka opini publik yang terbentuk akan semakin mengerucut pada sebuah keputusan atas isu tersebut. Foto hoax juga kerap memunculkan konflik dan kontroversi. Konflik dan kontroversi selalu menandai munculnya opini publik. Dalam pembentuan opini publik, segala bentuk isu (perselisihan, permasalahan, pertentangan) yang dipublikasi dan sifatnya kontroversial adalah permulaan dari pembentukan opini publik.

Selanjutnya, volume penyebaran opini berdasarkan kenyataan bahwa kontroversi itu menyentuh semua orang yang merasakan konsekuensi langsung dan tak langsung. Unggahan foto hoax @aganharahap juga memenuhi karakteristik ketetapan masa berlangsungnya isu karena di samping itu opini pun perlu diperhitungkan dan kekhasan isu memunculkan opini publik, karena berkaitan dengan identitas agama.

Menurut Nimmo opini merupakan kegiatan. Orang menyatakan opininya dengan melakukan segala jenis perbuatan. Setiap kegiatan yang dilakukan oleh seseorang pada umumnya memiliki kecenderungan, kecenderungan ini dapat diartikan dengan lebih menuju kearah mana kegiatan seseorang dilakukan (Nimmo, 2000). Demikian pula kegiatan opini terhadap suatu isu memiliki kecenderungan. Kecenderungan dalam kegiatan opini tersebut terdiri dari mendukung terhadap isu (favourable), netral dan tidak mendukung terhadap isu (unfavourable).

Foto Ahok dan Habib Rizieq Shihab yang tengah bersalaman komando, yang tersebar viral itu, dipastikan hoax atau hasil editan. Foto itu merupakan gabungan dari dua foto yang berbeda. Foto pertama, Ahok sedang berjabat tangan dengan Surya Paloh sambil tersenyum. Foto kedua, Habib Rizieq sedang tersenyum. Dari foto pertama, Ahok dan jabat tangannya diambil, sedangkan foto Surya Paloh dihilangkan. Lalu digabungkan dengan foto Habieb Rizieq yang dihilangkan foto tangannya lalu dimiringkan dan disesuaikan sedimikian rupa sehingga tampak Ahok dan Habib Rizieq saling berjabat tangan komando. Foto hoax tersebut dikecam oleh sejumlah warganet.

Situs berita bbc.com turut menguatkan bahwa foto tersebut adalah foto hoax seperti yang tertulis, foto Habib Rizieq yang berjabat tangan dengan Ahok ini adalah foto editan yang diolah oleh seorang "seniman Photoshop" bernama Agan Harahap yang memang dikenal dengan editan-editan foto tokoh terkenal dari aktris Angelina Jolie, Kim Kardashian, hingga petinju terkenal Filipina Manny Pacquiao. Dia mengunggah foto editan itu dalam akun Facebook-nya dan mendatangkan reaksi yang beragam. Orang-orang yang rajin mengikuti karyanya langsung mengerti bahwa itu adalah editan yang disengaja. "Damai dunia" kata seorang warganet. Tapi ada juga yang menganggapnya sangat 
serius. "Berhentilah hasut dan fitnah. Tambah ngerusak bangsa," kata warganet yang lain (“'Hoax' seputar kasus Ahok, FPI, 4 November,” 2016).

Ternyata sang pengedit foto tersebut adalah pemiliki akun instagram itu sendiri yaitu Agan Harahap. Dia mengaku sengaja membuat foto hoax itu dengan tujuan yang mengarah seperti yang disebutkan Dan Nimmo soal karakteristik opini publik. Ini didapatkan dari hasil wawancara singkat bersama pemilik akun lewat Direct Message (DM) akun Instagramnya. "Iya. Capek aja liat orang-orang berantem di TL (Timeline) jadi gua damaikan aja." Agan Harahap mencoba mengarahkan agar pihak-pihak yang pro dan kontra dalam kasus penistaan agama oleh Ahok tersebut bisa berdamai. Makna komunikasi yang dibangun Agan Harahap dengan cepat membentuk opini publik, karena difasilitasi oleh daya pikat yang dihasilkan melalui komunikasi melalui internet.

Terdapat keseragaman pendapat antara PGI dan HKBP mereka tentang pendapat mereka terkait kasus penistaan agama yang dilakukan Ahok, yaitu bahwa kasus Ahok sangat dekat dengan isu SARA (suku, agama dan ras), yang mana sangat sensitif di Indonesia. Kemudian isu SARA ini dimanfaatkan oleh sekelompok orang dan dijadikan bahan politik. Baik PGI dan HKBP mengemukakan bahwa kasus Ahok sangat lekat dengan isu SARA, yang dianggap kedua ormas Kristen sangat sensitif di Indonesia. Meskipun, HKBP apa yang di lakukan Ahok di Pulau Seribu adalah salah. Ahok tidak memiliki hak dan kapasitas untuk menafsirkan Al-Maidah ayat 51. Karena Ahok bukan seorang pemuka agama Islam dan bahkan bukan seorang muslim. Tapi baik PGI dan HKBP, mengaku Ahok terbawa dengan pengalamannya di Belitung Timur di mana, perkataan Ahok menurut PGI dan HKBP dilatarbelakangi dari pengalaman ketika Ahok mencalonkan diri menjadi Bupati Belitung Timur.

Pihak HKBP mengatakan bahwa menurut UUD 1945, setiap warga negara Indonesia memiliki hak untuk dipilih. Lantas, HKBP memiliki opini bahwa karena Ahok berbeda dengan mayoritas, hal tersebut menjadi hambatan bagi Ahok untuk terpilih kembali di Pilkada Jakarta. Masih menurut HKBP faktor ekonomi, sosial dan budaya juga menjadi dasar penyebab masyarakat Indonesia gampang terprovokasi, sehingga sangat mudah apabila disulut opini tertentu. PGI menyebutkan, bahwa kondisi sosial masyarakat Indonesia dalam suasana yang kacau. Banyak masyarakat yang telah tidak peduli pada kebenaran suatu isu. Kurangnya minat baca adalah salah satu faktor.

Baik pihak PGI dan HKBP menyadari bahwa foto Ahok dan Habib Rizieq Shihab yang diunggah Agan Harahap dan kemudian viral di media sosial tersebut adalah foto hoax. Namun mereka berpendapat bahwa pesan yang disampaikan oleh foto tersebut baik. Ketika dua orang publik figur yang dalam opini publik sedang berseteru kini telah berdamai. Foto hoax ini dalam opini PGI dan HKBP juga menunjukkan respons yang baik dari kaum mayoritas.

Baik PGI dan HKBP mengakui banyaknya opini mayoritas, dalam arti mendukung agar Ahok dipidanakan, dalam foto hoax Agan Harahap terkait kasus penistaan agama, mengakibatkan opini minoritas cenderung bungkam. 
Ormas PGI dan HKBP di Medan memilih tidak berkomentar dan memberikan opini di media sebagai ruang publik karena tak ingin memperkeruh situasi. Itu dilakukan semata-mata untuk menjaga kestabilan politik dan menjaga agar kondisi tidak semakin ricuh. Apalagi HKBP dan PGI menilai tidak ada unsur kebencian dalam foto hoax tersebut. Mereka pun mendoakan agar foto tersebut dapat menjadi kenyataan.

PGI dan HKBP menyebutkan, apabila mencoba melawan opini mayor, maka dikhawatirkan akan menimbulkan suasana yang ricuh dan mengganggu keamanan negara. Bagaimanapun PGI dan HKBP menganggap kestabilan politik dan menjaga kondisi tidak semakin buruk adalah sebaik-baiknya sikap. Karena menurut kedua ormas ini, isu penistaan agama yang menimpa Ahok adalah isu yang sangat sensitif.

PGI dan HKBP menyebutkan, bahwa Aksi Seribu Lilin pasca jatuhnya vonis terhadap Ahok merupakan bentuk solidaritas dan puncak semangat kelompok beropini minor untuk Ahok. Karena menurut informan, Ahok merupakan pemimpin yang baik dan berhasil membangun Jakarta. Aksi ini bisa disebut yang dalam asumsi Teori Spiral Keheningan, dikenal sebagai peran minoritas. Terkadang minoritas yang diam mulai bangkit. Kelompok ini, yang disebut hard core, tetap berada pada ujung akhir dari proses spiral keheningan tanpa memedulikan ancaman akan isolasi. Aksi solidaritas ini berusaha untuk menentang cara berpikir atau opini publik yang dominan. PGI dan HKBP juga mengatakan mengatakan peran media sangat membantu dalam menyelesaikan isu penistaan agama yang berbau SARA ini. Mereka berharap berita yang berimbang untuk memberikan pemahaman kepada masyarakat. Serta dapat memberikan pengetahuan kepada masyarakat untuk dapat membedakan berita hoax dan berita yang benar.

Peneliti juga menemukan hal menarik dari penelitian ini. Baik PGI dan HKBP berpendapat bahwa foto hoax Ahok dan Habib Rizieq Shihab adalah sesuatu yang positif. Tapi di sisi lain, kedua ormas Kristen ini tetap keberatan dengan hukuman pidana yang dijatuhkan pada Ahok, meskipun Ahok sudah dijatuhi hukuman yang berkekuatan hukum tetap. Ternyata, foto hoax yang dianggap sebagai bentuk kesepakatan perdamaian oleh ormas Kristen, tidak memberikan hal serupa pada pendapat mereka terkait kasus penistaan agama yang dilakukan Ahok. Benar juga seperti yang diungkapkan Ahmad Budiman, unggahan bohong (hoax) melalui media sosial tidak boleh dibiarkan, karena informasi yang tidak dilandasi fakta peristiwa cenderung menimbulkan ketidakpastian informasi, menciptakan opini publik yang tidak berlandaskan fakta berita, dan menyebabkan keresahan dalam masyarakat (Budiman, 2017). Kesadaran masyarakat untuk dengan cermat mengetahui proses produksi dan makna unggahan bohong yang diterimanya sangat diutamakan.

\section{PENUTUP}

Pendapat Ormas Agama Kristen PGI dan HKBP tentang foto hoax dari akun Instagram @aganharahap terkait kasus penistaan agama yaitu Positif. Mereka berpendapat bahwa foto tersebut tidak memiliki unsur kebencian dan pesan 
yang disampaikan oleh foto tersebut baik, di mana indahnya Indonesia ketika dua orang publik figur yang sedang berseteru kini telah berdamai. Respons ini diberikan informan, bahwa rangsangan yang diberikan peneliti berupa foto, menunjukkan respons yang positif dari ketiga informan. Opini minoritas cenderung bungkam. Padahal sesungguhnya kaum minoritas tidak bungkam namun hanya menyadari bahwa sebuah simbol yang tidak memiliki unsur kebencian tidak perlu untuk dikhawatirkan. Namun, walau bagaimanapun kestabilan politik dan menjaga kondisi tidak semakin buruk adalah sebaikbaiknya sikap. Meskipun puncak dari semuanya adalah sebuah aksi yang mereka sebut dengan Aksi Seribu Lilin Untuk Ahok.

\section{REFERENSI}

Agan Harahap, Seniman Ahlinya "Manipulasi Foto." (2014). Retrieved September 27, 2017, from https:/ / hot.detik.com/art/2719114/aganharahap-seniman-ahlinya-manipulasi-foto

Ardianto, \& Elvinaro. (2012). Analisis Wacana Kritis Pemberitaan Harian Pikiran Rakyat dan Harian Kompas sebagai Public Relations Politik dalam Membentuk Branding Reputation Presiden Susilo Bambang Yudhoyono (SBY). Jurnal Ilmu Komunikasi, 2(21). https:/ / doi.org/10.1002/9781119208501.ch9

Budiman, A. (2017). Berita Bohong (Hoax) di Media Sosial dan Pembentukan Opini Publik. Retrieved September 27, 2017, from http:/ / berkas.dpr.go.id/puslit/files/info_singkat/Info Singkat-IX-1-IP3DI-Januari-2017-181.pdf

Dahlgren, P. (2003). Reconfiguring Civic Culture in the New Media Milieu. In Media and the Restyling of Politics (pp. 151-170). Retrieved from http:

Haryanto, S. (2015). Sosiologi Agama. Yogyakarta: Ar-Ruzz Media.

Hennessy, B. (1954). A Case Study of Intra-Pressure Group Conflicts: the United World Federalists. Journal of Politics, 16(1), 76-95. https:/ / doi.org/10.2307/2126339

Heriyanto, T. (2015). Jutaan Akun Instagram Ternyata Dikendalikan Robot. Retrieved September 27, 2017, from https://www.cnnindonesia.com/teknologi/20150707165310-18564989/jutaan-akun-instagram-ternyata-dikendalikan-robot?

"Hoax" seputar kasus Ahok, FPI, 4 November. (2016). Retrieved November 3, 2016, from https:/ / www.bbc.com/indonesia/trensosial-37843842

Kopko, K. C. (2012). Religious Identity and Political Participation in the mennonite Church USA. Politics and Religion, 5(2), 367-393. https:// doi.org/10.1017/S1755048312000077

McLuhan, E. (2008). Marshall McLuhan's Theory of Communication. Global Media Journal, 1(1), 25-43. Retrieved from http:/ / www.doaj.org/doaj?func=fulltext\&aId=407419

Morrisan. (2013). Teori Komunikasi Individu Hingga Massa. Jakarta: Kencana Prenada Media Group.

Nasrullah, P. (2015). Media Sosial. Bandung: Simbiosa Rekatama Media. Newsom, T., \& Kruckeberg. (2000). This is PR, The Realities of Public Relations. 
Belmont: Wadsworth.

Nimmo, D. (2000). Komunikasi Politik: Khalayak dan Efek. Bandung: Remaja Rosdakarya.

Noelle-Neumann, E. (2008). The Spiral of Silence. In R. West \& L. Turner (Eds.), Pengantar Teori Komunikasi : Analisis dan Aplikasi (3rd ed.). Jakarta: Salemba Humanika.

Olii, H. (2007). Opini Publik. Jakarta: Indeks.

Pidato di Kepulauan Seribu dan hari-hari hingga Ahok menjadi tersangka.

(2016). Retrieved November 17, 2016, from

http://www.bbc.com/indonesia/indonesia-37996601

Saputra, R. M. (2017). OPINI: Fenomenan Hoax di Era Digital. Retrieved

September 27, 2017, from http:/ / www.klikbontang.com/berita-11036opini-fenomenan-hoax-di-era-digital.html\#page2

Sudibyo, A. (2001). Media Politik dan Pertarungan Wacana. Yogyakarta: LKiS. 